\title{
BORON AFFECTS THE GROWTH AND ULTRASTRUCTURE OF CASTOR BEAN PLANTS
}

\author{
Denis Herisson da Silva ${ }^{1}$; Monica Lanzoni Rossi²; Antonio Enedi Boaretto ${ }^{3}$; Neusa de Lima \\ Nogueira $^{2}$; Takashi Muraoka ${ }^{4 *}$ \\ ${ }^{1}$ USP/CENA - Programa de Pós-Graduação em Ciências - C.P. 96 - 13400-970 - Piracicaba, SP - Brasil. \\ ${ }^{2}$ USP/CENA - Laboratório de Histologia e Biologia Estrutural de Plantas - C.P. 96 - 13400-970 - Piracicaba, SP \\ - Brasil. \\ ${ }^{3}$ USP/CENA - Laboratório de Nutrição Mineral de Plantas - C.P. 96 - 13400-970 - Piracicaba, SP - Brasil. \\ ${ }^{4}$ USP/CENA - Laboratório de Fertilidade dos Solos - C.P. 96 - 13400-970 - Piracicaba, SP - Brasil. \\ *Corresponding author <muraoka@cena.usp.br>
}

ABSTRACT: The cultivation of oleaginous plants like the castor bean guarantees employment for agricultural families and can contribute in energy and chemical sectors, especially in the northeastern semi-arid regions of Brazil. Boron (B) deficiency is a widespread nutritional disorder despite the fact that various anthropogenic sources with high B content may increase soil B to toxic levels for plants. The present study was designed to investigate the ultrastructural effects of boron deficiency and toxicity on castor bean plants which were grown under greenhouse condition using plastic containers with $10 \mathrm{~L}$ of nutrient solution. Boron treatments comprised: control (no B); $0.27 \mathrm{mg} \mathrm{L}^{-1}, 5.40 \mathrm{mg} \mathrm{L}^{-1} \mathrm{~B}$ pots (one plant per pot), tested in a completely randomized design with three replicates. The dry matter of all plant parts and $\mathrm{B}$ concentration were determined. Cellular ultrastructure was evaluated by transmission and scanning electron microscopy on samples of leaves and petioles. Dry matter yield was affected by the B absence treatment but there was no difference for the $5.4 \mathrm{mg} \mathrm{L}^{-1} \mathrm{~B}$ (toxic conditions) treatment. A marginal leaf burn at edge and tips of oldest leaves and absence of starch granules in chloroplasts were noted for the B toxicity treatment. The deformation of the youngest leaves, the death of the apical meristem as well as the swelling of the middle lamella, absence of starch granules in chloroplasts and petiole vessels untidily were observed in the B absent treatment. It is concluded that the production and development of castor bean plants is affected by boron deficiency, but not for boron toxicity conditions.

Key words: electron microscopy, middle lamellae, micronutrient, xylem, starch

\section{BORO AFETA O CRESCIMENTO E A ULTRA-ESTRUTURA DA MAMONEIRA}

RESUMO: A mamoneira é uma oleaginosa com grande potencial para a geração de renda na agricultura familiar e para produção de matéria prima para a indústria química e setor energético brasileiro, especialmente em regiões do semi-árido nordestino. A deficiência de boro (B) ocorre de forma generalizada no Brasil e a aplicação excessiva deste micronutriente pode causar toxicidade. Este estudo avalia o desenvolvimento e os efeitos ultra-estruturais de deficiência e toxicidade de boro em mamoneira. $\mathrm{O}$ experimento foi realizado em condições de casa de vegetação, com vasos de $10 \mathrm{~L}$ de solução nutritiva. Foram utilizados três tratamentos: testemunha (sem B); 0,27 e 5,40 $\mathrm{mg} \mathrm{L}^{-1} \mathrm{~B}$, uma planta por vaso, em delineamento experimental inteiramente ao acaso com três repetições. A produção de matéria seca de cada parte da planta foi avaliada e o teor de boro determinado. Foram observados os efeitos morfológicos e as alterações na ultra-estrutura celular nas folhas e pecíolos, através da técnica de microscopia eletrônica de transmissão e varredura. A produção de matéria seca da mamoneira foi afetada em condições de deficiência de boro, mas não em condições de toxicidade $\left(5,4 \mathrm{mg} \mathrm{L}^{-1} \mathrm{~B}\right)$. Neste último tratamento foram constatadas cloroses nos bordos de folhas velhas e ausência de grânulos de amido. Na omissão de boro, as plantas apresentaram deformação de folhas novas, morte do meristema apical, engrossamento da lamela média, ausência de grânulos de amido nos cloroplastos e desorganização dos vasos condutores do pecíolo. O desenvolvimento e a produção da mamoneira são afetados em condições de deficiência de boro mas não na condição de toxicidade.

Palavras-chave: microscopia eletrônica, lamela média, micronutriente, xilema, amido 


\section{INTRODUCTION}

The castor bean plant (Ricinus communis L.) is an African euphorbiaceae (Joly, 2002), whose oil is the main product of the crop, supplying the medicinal, cosmetic and automotive industries. Nowadays, with increasing prices of the crude oil, the castor bean cultivation emerges as a promising activity for biodiesel production, providing income in resource poor areas of Brazil (Savy Filho, 2005).

Boron (B) deficiency occurs in a large frequency in agricultural areas,,inducing to an excessive application of this nutrient (Gupta, 1979; Blevins \& Lukaszewsky, 1998; Shorrocks, 1997). Davies \& Albrigo (1994), Mattos Júnior et al. (2001), and Havlin et al. (2005) have underlined the short interval that exists between the B deficiency and toxicity. The deficiency of micronutrients in Ricinus communis was described by Lange et al. (2005). However, the ultrastructure changes under B deficiency and the boron toxicity in castor bean plants are not yet known.

The determination of the B primary function is one of the current challenges related to the mineral nutrition of plants (Blevins \& Lukaszewsky, 1998). The primary function of $\mathrm{B}$ in the cell wall structure could explain all effects related to boron deficiency (Brown $\& \mathrm{Hu}, 1997)$.

The swelling of the cell walls under boron deficiency and its relationship with the borate-ester crosslinked rhamnogalacturonan II dimer (RG-II) was described by Ishii et al. (2001). The presence of RG-II in cell walls in families of Brassicaceae, Cucurbitaceae, Leguminosae, Apiaceae, Chenopodiaceae, Solanaceae, Asteraceae, Liliaceae, Araceae, Amaryllidaceae and Gramineae was described by Matoh et al. (1996). Thus, there is a strong evidence that suggests the existence of a RGII complex also in Ricinus communis, however, not yet been found in this species or another one from the euphorbiaceae family.

The objective of this study was to investigate ultrastructural changes under B deficiency and toxicity conditions in Ricinus communis L. as well as the effects on castor bean production.

\section{MATERIAL AND METHODS}

The experiment was carried out in a greenhouse in Piracicaba, São Paulo state, Brazil (22 $42^{\prime} 30^{\prime \prime}$ S, 47 38'01' W, $554 \mathrm{~m}$ above sea level). Castor bean seeds (savana $\mathrm{cv}$.), were sown in washed sand which received 1/5 diluted nutrient solution (Johnson et al., 1957) supplied daily, without boron. The greenhouse deionized water presented $50 \mu \mathrm{g} \mathrm{L}^{-1}$ of boron, determined previously by Inductively Coupled Plasma Mass
Spectrometry (ICP MS). The composition of the nutrient solution was $\mathrm{N}$ : $224 \mathrm{mg} \mathrm{L}^{-1}$; $\mathrm{P}: 62 \mathrm{mg} \mathrm{L}^{-1}$; $\mathrm{K}: 235 \mathrm{mg} \mathrm{L}^{-1}$; Ca: $160 \mathrm{mg} \mathrm{L}^{-1}$; $\mathrm{Mg}: 24 \mathrm{mg} \mathrm{L}^{-1}$; $\mathrm{S}$ : $32 \mathrm{mg} \mathrm{L}^{-1}$; Cl: $1.77 \mathrm{mg} \mathrm{L}^{-1}$; $\mathrm{Cu}: 0.032 \mathrm{mg} \mathrm{L}^{-1}$; $\mathrm{Fe}$ : $1.12 \mathrm{mg} \mathrm{L}^{-1}$; Mn: $0.11 \mathrm{mg} \mathrm{L}^{-1}$; Mo: $0.05 \mathrm{mg} \mathrm{L}^{-1}$; $\mathrm{Zn}$ : $0.131 \mathrm{mg} \mathrm{L}^{-1}$.

The experiment was set up with three treatments $\left(0 ; 0.27 ; 5.40 \mathrm{mg} \mathrm{L}^{-1}\right.$ of boron) and three replicates, in a randomized experimental design. Castor beans plants (one plant per pot) were transplanted ten days after emergence to plastic pots with $10 \mathrm{~L}$ of nutrient solution with $1 / 5$ of salt concentration. After a week, the solutions were replaced by $1 / 2$, and in the following week they were replaced by complete solutions (conductivity of $1.6 \mathrm{mS}$ ). The solutions were replaced every three weeks.

Plants were collected 60 days after germination, and samples were visualized using a transmission and scanning electron microscope.

\section{Transmission Electron Microscopy}

Samples from the blades of new leaves that showed deficiency of boron $\left(0 \mathrm{mg} \mathrm{L}^{-1}\right.$ of $\left.\mathrm{B}\right)$ and new leaves of the control treatment $\left(0.27 \mathrm{mg} \mathrm{L}^{-1}\right.$ of $\left.\mathrm{B}\right)$ were collected to evaluate ultrastructural symptoms of the boron deficiency. The effects of toxicity were investigated on samples of old leaf blades presenting marginal chlorosis $\left(5.4 \mathrm{mg} \mathrm{L}^{-1}\right.$ of $\left.\mathrm{B}\right)$ and of old leaf blades from the control treatment $\left(0.27 \mathrm{mg} \mathrm{L}^{-1}\right.$ of $\left.\mathrm{B}\right)$.

Afterwards the leaf samples were fixed in $2 \%$ glutaraldehyde, $4 \%$ paraformaldehyde, $5 \mathrm{mM} \mathrm{CaCl}_{2}$, in a $0.2 \mathrm{M}$ pH 7.5 sodium caccodilate buffer (Karnovsky, 1965). After $2 \mathrm{~h}$ at $4^{\circ} \mathrm{C}$ they were washed with buffer and post fixed for $1 \mathrm{~h}$ in similarly buffered $1 \% \mathrm{OsO}_{4}$ solution. After washing with a $0.9 \% \mathrm{NaCl}$ solution, these samples were contrasted in loco with $2.5 \%$ uranyl acetate at $4^{\circ} \mathrm{C}(12 \mathrm{~h})$, dehydrated in an increasing acetone series $(25 \%, 50 \%, 75 \%, 90 \%$ and $100 \%)$ and inserted in Spurr resin.

The ultra thin cuts $(60-90 \mathrm{~nm})$ were obtained through the use of a diamond blade in a Porter-Blum MT Ultracut, placing on 300 mesh copper nets, and submitted to double coloration (Reynolds, 1963), using uranyl acetate and lead citrate solutions. These ultra thin cuts were examined using the Transmission Electron Microscope Zeiss EM-109 operating at $50 \mathrm{kV}$.

\section{Scanning Electron Microscopy}

The petiole tissues of new leaves from boron absent $\left(0 \mathrm{mg} \mathrm{L}^{-1}\right.$ of $\left.\mathrm{B}\right)$ and control treatments $(0.27$ $\mathrm{mg} \mathrm{L}^{-1}$ of B) were used to evaluate the symptoms of boron deficiency. There was not difference between the petiole morphology of plants treated with the boron toxicity and the control, and therefore, these samples were not analyzed. These samples were pro- 
cessed using $2 \%$ glutaraldehyde, in a $0.2 \mathrm{M}$ caccodilate buffer. After $2 \mathrm{~h}$ at $4^{\circ} \mathrm{C}$, these samples were washed in $0.1 \mathrm{M}$ caccodilate buffer and dehydrated with sequences of acetone series $(25 \%, 50 \%, 75 \%, 90 \%$ and $100 \%)$. They were then dried to critical point (Balzers CPD030), and covered with gold (MED010-Balzers). The coated specimens were examined in a scanning electron microscope operating at $20 \mathrm{kV}$.

\section{Determination of total B content of specimens}

Samples weighed exactly $0.2 \mathrm{~g}$ after being dried for $24 \mathrm{~h}$ at $105^{\circ} \mathrm{C}$, and were put into ceramic crucibles and ashed for $2 \mathrm{~h}$ at $550^{\circ} \mathrm{C}$. The total boron content was determined by the azomethine- $\mathrm{H}$ method (Malavolta et al., 1997).

\section{Statistical Analysis}

Statistical analyses were made using Sigmaplot 2000 v. 6 and SAS version 8.02 (SAS Institute, Cary, NC). The Tukey test was used to compare the means of the treatments $(p<0.05)$.

\section{RESULTS AND DISCUSSION}

\section{Boron contents in plant pots and dry matter pro- duction}

The mean B content (in dry mass) in new leaves was $12 \mathrm{mg} \mathrm{kg}^{-1}$ for the $\mathrm{B}$ absent treatment and $28 \mathrm{mg} \mathrm{kg}^{-1}$ for the treatment of $0.27 \mathrm{mg} \mathrm{L}^{-1} \mathrm{~B}$. The $\mathrm{B}$ content in old leaves was $40 \mathrm{mg} \mathrm{kg}^{-1}$ for the treatment of $0.27 \mathrm{mg} \mathrm{L}^{-1} \mathrm{~B}$ and $450 \mathrm{mg} \mathrm{kg}^{-1}$ for the treatment of $5.4 \mathrm{mg} \mathrm{L}^{-1} \mathrm{~B}$. The B content (dry mass) in petioles of new leaves was $11 \mathrm{mg} \mathrm{kg}^{-1}$ for the absent treatment and $20 \mathrm{mg} \mathrm{kg}^{-1}$ for the treatment of $5.4 \mathrm{mg}$ $\mathrm{L}^{-1} \mathrm{~B}$.

The mean of dry matter weight per plant of the B deficiency treatment plants was smaller than for the treatments of $0.27 \mathrm{mg} \mathrm{L}^{-1} \mathrm{~B}$ and $5.4 \mathrm{mg} \mathrm{L}^{-1} \mathrm{~B}$ (Figure 1). The seed production of plants was strongly affected by B absence. However, there were no differences in seed production, as well as dry matter weight, between the $0.27 \mathrm{mg} \mathrm{L}^{-1} \mathrm{~B}$ and $5.4 \mathrm{mg} \mathrm{L}^{-1} \mathrm{~B}$.

\section{Boron deficiency and toxicity symptoms}

The first symptoms of toxicity appeared for the treatment of $5.4 \mathrm{mg} \mathrm{L}^{-1}$ of $\mathrm{B}$, on the $15^{\text {th }}$ day after transplanting. The observed symptom included chlorosis on the edges of the leaves and spots. These toxicity symptoms were evident $\left(5.4 \mathrm{mg} \mathrm{L}^{-1}\right.$ of $\left.\mathrm{B}\right)$, although there was no significant effect on growth, fruit and seed production. This fact indicates that B does not move readily from the old leaves to growing tissues (phloem mobility)

Boron generally moves through the xylem, governed by the transpiration flow, with a tendency to bind

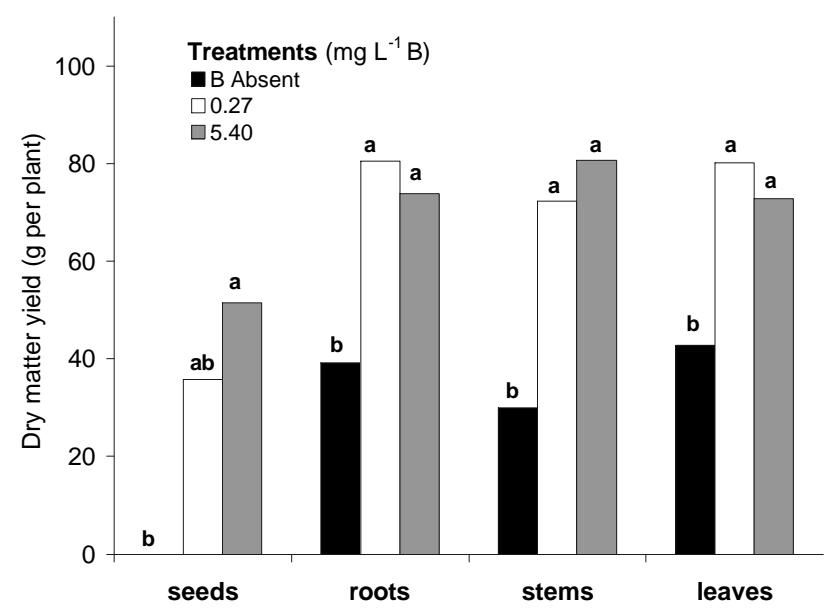

Figure 1 - The effect of B treatments on dry matter yield of castor bean plant. Bar graphs of specific parts with the same letter are not different (Tukey test, $p<0.05)$.

on cell wall pectin in leaves. For old leaves, the amount of transpiration along time is large, explaining the high B contents (Furlani, 2004). However, the high supply of B is not correlated with an increase of total B content in the cell walls (Matoh \& Kobayashi, 2002). Besides, this micronutrient forms various biological compounds also in the cytoplasm, such as complexes of B (boric acid) with sugars, phenols, organic and polymeric acids (Dembitsky et al., 2002).

Boron deficiency symptoms appeared first in new leaves at the $40^{\text {th }}$ day after transplanting, such as deformity and necrosis of leaf edges (Figure 2). Furthermore, minus-boron petioles showed hyperplasia and necrotic spots. This can be explained by an interference in the lignin synthesis under low B supply (Marschner, 1995). These deficiency symptoms indicate that the B phloem mobility in this species is probably low or restricted. In contrast, the mobility of B in several sorbitol, mannitol, and dulcitol rich species has been verified (Brown \& Hu, 1996; Hu et al., 1997).

The reproductive growth, especially flowering and seed set and seed yield, were more sensitive to B deficiency than the vegetative growth. Stem and leaf biomass were also negatively affected by the absence of B (Figure 1). Necrosis of the apical meristem of shoot tips was followed by a loss of apical dominance and highly branched shoot architecture (Figure 2).

The boron deficiency interferes in IAA levels in apical tissues, phenols and quinones levels, followed by a loss of apical dominance (Coke \& Whittington, 1968). This effect was detected in an experiment with micronutrient starvation in nutrient solution in castor bean by Lange et al. (2005). However, it is possible that most effects of boron deficiency on the physiologic processes are secondary effects (Marschner, 1995). 


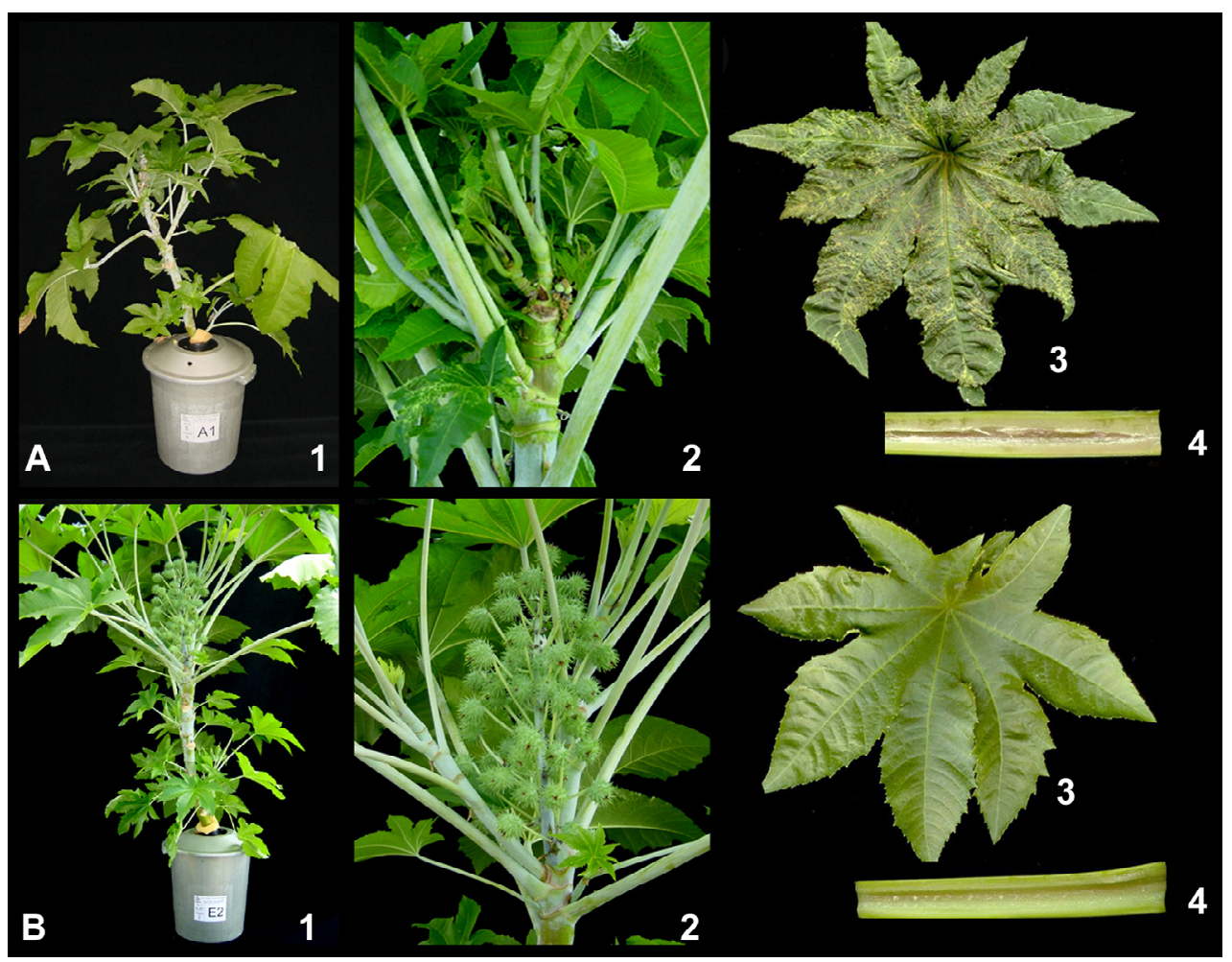

Figure 2 - Symptoms of boron deficiency in Ricinus communis L. A: Boron absent treatment; B: 0.27 mg L-1 B. 1- General; 2- Fruits; 3- New leaf; 4- Petiole cross-section.

\section{Ultrastructural evidences of boron deficiency and toxicity}

The major symptom of boron deficiency was the thickening of the middle lamellae (Figure 3). This fairly and rigid layer is a structural component, located between two adjacent primary cell walls, composed of pectin. The thickening of the middle lamella could be explained by the structural role of boron in relation to the polysaccharide present in the pectin, especially the formation of dimeric B-Rhamnogalacturonan-2 (BRG-II) in a borate-ester crosslinking (Kobayashi et al., 1996; Ishii \& Matsunaga, 1996; O'Neill et al., 1996). This crosslink forms a macromolecular complex that controls the cellular growth (Fleischer et al., 1999) and mechanical properties of primary cell walls (Ishii et al., 2001). Probably, on the B-deficient medium, the B-RGII formation was affected, with the increase of monomers, thickening the middle lamella and affecting the cellular growth (Figure 3).

Furthermore, besides playing a role in the function and stabilization of cell walls in plants (O'Neill et al., 1996), there is also considerable information that connects B with membrane structure and function (Pollard et al., 1977), as well as cellular homeostasis, suggesting that the B exerts some functions in the cytoplasm (Gassert et al., 2002).

A low level of starch granules was observed in chloroplast of plants under B absence (Figure 3).
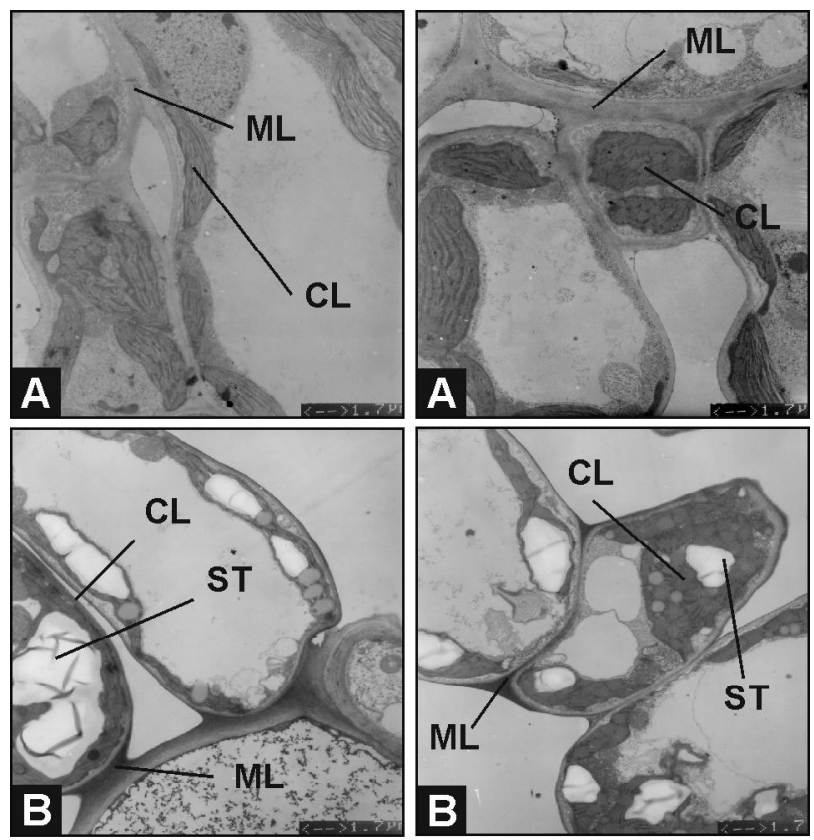

Figure 3 - Spongy mesophyll of new leaves of Ricinus communis L. A: Boron absent treatment B: Boron treatment with $0.27 \mathrm{mg} \mathrm{L}^{-1}$. The thickening of the middle lamellae (ML), and starch granules absence (ST) in chloroplasts (CL) in boron absent treatment. Scale bar $=1.7 \mu \mathrm{m}$.

In $\mathrm{B}$ deficient plants, the carbohydrates synthesis is affected on account of the inhibition of the fosforilases action or the reduction in the uracyl synthesis, pre- 


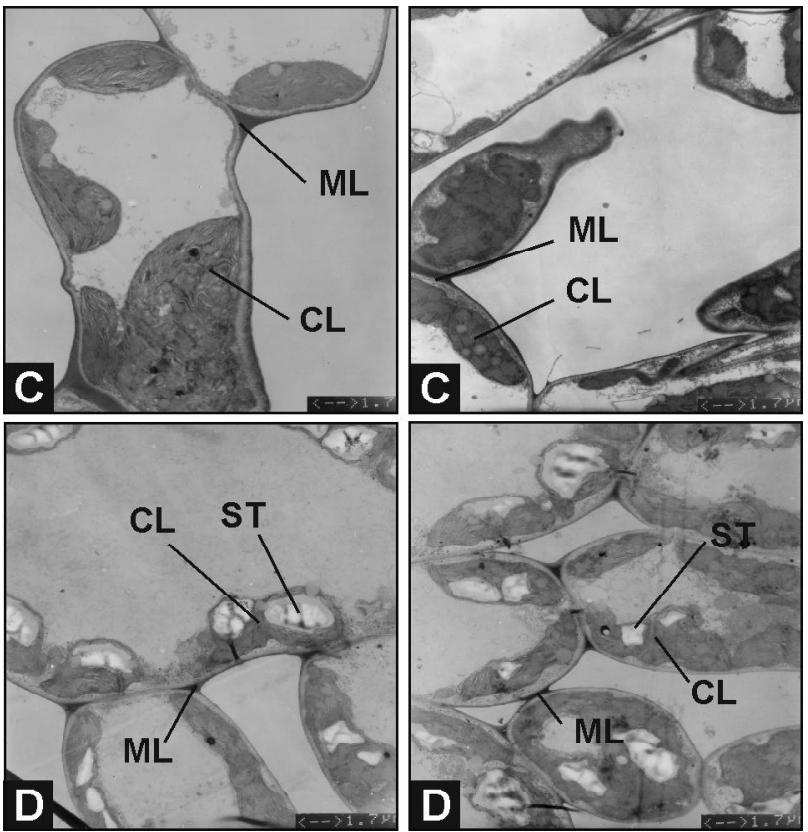

Figure 4 - Spongy mesophyll of old leaves of Ricinus communis L. C: Boron toxicity treatment with $5.4 \mathrm{mg} \mathrm{L}^{-1}$ D: Boron treatment with $0.27 \mathrm{mg} \mathrm{L}^{-1}$. The absence of starch granules in B toxicity. Scale bar $=1.7 \mu \mathrm{m}$.

cursor of the glycose uridin diphosphate (Loué, 1993; Marschner, 1995).

The B toxicity symptoms appeared before those of B deficiency, but were less harmful to the whole plant growth. The absence of starch granules in chloroplasts in plants grown in the $5.4 \mathrm{mg} \mathrm{L}^{-1} \mathrm{~B}$ treatment occurred also in all specimens (Figure 4). However, the exact cause of this effect is not known, and the same alteration in the carbohydrate metabolism due to B toxicity was verified by Scott (1960) for sunflower plants.

The starch biosynthesis occurs inside the chloroplasts and amyloplasts where the enzymes that catalyze the polymerics synthesis are located, using as basic material the sucrose produced from photosynthesis (Galliard \& Bowler, 1987). Thus, a reduction in the available sucrose for metabolic processes could lead a decrease on the starch production (Zrenner et al., 1995). Most of the B is present in the apoplast (Matoh, 1997), but it is possible that B can also be present in the cytoplasm under high $\mathrm{B}$ supply.

It is supposed that B excess could affect indirectly the formation of starch because of the properties of the boric acid to form complexes with a large number of sugars. Although B does not form complexes with sucrose (Marschner, 1995), this micronutrient can form complexes with other sugars, phenols, organic and polymeric acids (Dembitsky et al., 2002).
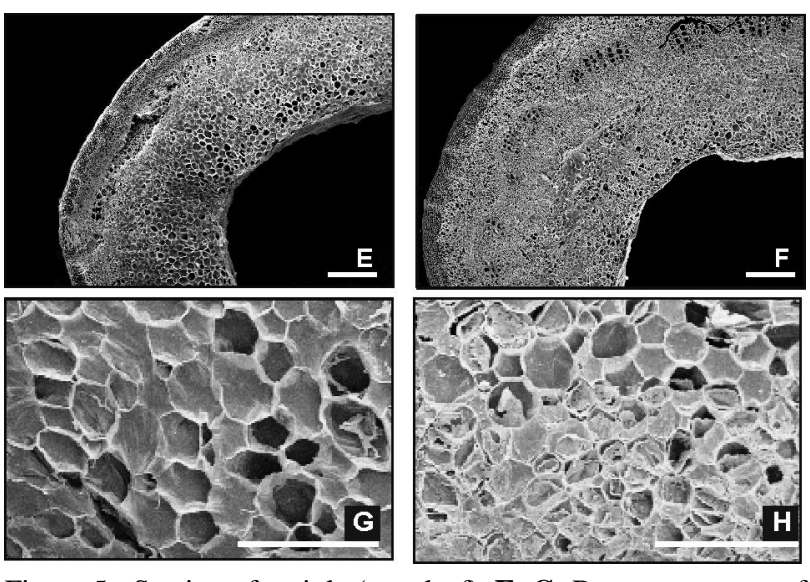

Figure 5 - Section of petiole (new leaf). E, G: Boron treatment of $0.27 \mathrm{mg} \mathrm{L}^{-1} ; \mathbf{F}, \mathbf{H}$ : Boron absent treatment. Primary symptoms of boron deficiency were thickened petioles with necrosis. Scale bar $(\mathrm{E}, \mathrm{F})=0.6 \mathrm{~mm}$. Details of irregular edges part of vessels in $\mathbf{H}$. Scale bar $(\mathrm{G}, \mathrm{H})=$ $250 \mu \mathrm{m}$.

The petioles of new leaves grown under B deficient medium were thicker, irregular with necrotic spots. In a cross-sectional view, the petioles showed hyperplasia, and when observed by scanning electronic microscopy, the xylem vessels edges were more irregular (Figure 5). There was not difference between the petioles of plants grown in high B supply $(5.40 \mathrm{mg}$ $\mathrm{L}^{-1} \mathrm{~B}$ treatment $)$ and control $\left(0.27 \mathrm{mg} \mathrm{L}^{-1}\right.$ of $\mathrm{B}$ treatment).

The irregular lignifications of the cell walls and a sensitive reduction in total lignin content as pointed out by Marschner (1995) and the effects of boron on growth and lignification in sunflower plants is due to peroxidase enzyme contents (Dutta \& McIlrath, 1964). In addition, the role of boron in the lignin synthesis can be related to the formation of borate complexes with phenols, regulating the rate of free phenols that are precursors of the lignin synthesis (Lewis, 1980; Pilbeam \& Kirkby, 1983; Shkolnik, 1984). Although the lignification process is associated with the secondary cell wall, it generally begins in the middle lamella and primary cell wall, sites where the boron deficiency seems to occur initially.

\section{CONCLUSIONS}

Dry matter and seed yield are negatively affected under boron deficient conditions. However, the high boron supply, twenty times more than a usual nutrient solution, was not able to decrease the development of Ricinus communis. The boron deficiency causes the swelling of middle lamellae and irregular growth of petiole vessels. Both deficiency and toxicity affects the starch synthesis in chloroplasts. 


\section{ACKNOWLEDGEMENTS}

To CNPq and FAPESP for the financial support. To NAP-MEPA / ESALQ-USP for providing the access to a scanning and transmission electronic microscope. To Dr. M. Tchienkoua, Institute of Agronomic Research and Development, Yaounde, Cameroon, for the English revision of this paper.

\section{REFERENCES}

BLEVINS, D.G.; LUKASZEWSKI, K.M. Boron plant structure and function. Annual Review of Plant Physiology and Plant Molecular Biology, v.49, p.481-500, 1998.

BROWN, P.H.; HU, H. Does boron play only a structural role in the growing tissues of higher plants? Plant Soil, v.196, p.211215, 1997

BROWN, P.H.; HU, H. Phloem mobility of boron in species dependent: evidence of boron mobility in sorbitol-rich species. Annals of Botany, v.77, p.497-505, 1996.

COKE, L.; WHITTINGTON, W.J. The role of boron in plant growth. IV. Interrelationships between boron and indol-3yl-acetic acid in the metabolism of bean radicles. Journal of Experimental Botany, v.19, p.295-308, 1968.

DAVIES, F.S.; ALBRIGO, L.G. Environmental constraints on growth, development and physiology of citrus. In: DAVIES, F.S.; ALBRIGO, L.G. Citrus. Wallingford: CAB International, 1994. p.52-82.

DEMBITSKY, V.M.; SMOUM, R.; AL-QUNTAR, A.A.; ALI, H.A.; PERGMAMENT, I.; SREBNIK, M. Natural occurrence of boroncontaining compounds in plants, algae and microorganisms. Plant Science, v.163, p.931-942, 2002.

DUTTA, T.R.; McILRATH, J. Effects of boron on growth and lignification in sunflower tissue and organ cultures. Botanical Gazette, v.125, p.89-96, 1964.

FLEISCHER, A.; O' NEILL, M.A.; EHWALD, R. The pore size of nongraminaceous plant cell walls is rapidly decreased by borate ester crosslinking of the pectic polysaccharide rhamnogalacturonan II. Plant Physiology, v.121, p.829-838, 1999.

FURLANI, A.M.C. Nutrição mineral. In: KERBAUY, G.B. Fisiologia vegetal. Rio de Janeiro: Guanabara Koogan, 2004. p.40-75.

GALLIARD, T.; BOWLER, P. Morphology and composition of starch. In: GALLIARD, T. Starch properties and potential. Chichester: Wiley, 1987. p.55-78.

GASSERT, B.; SPRICH, E.; PFEFFER, H.; DANNEL, F.; WIRÉN, N.; ROMHELD, V. Characterization of boron uptake in higher plants. In: GOLDBACH, H.E.; RERKASEM, B.; WIMMER, M.A.; BROWN, P.H.; THELLIER, M.; BELL, R.W. (Ed.) Boron in plant and animal nutrition. New York: Kluwer Academic, 2002. p.119-126.

GUPTA, U.C. Boron nutrition of crops. Advances in Agronomy, v.31, p.273-307, 1979.

HAVLIN, J.L.; BEATON, J.D.; TISDALE, S.L.; NELSON, W.L. Soil fertility and fertilizers: an introduction to nutrient management. 7 ed. Englewood Cliffs: Prentice Hall, 2005. 515p.

HU, H.; PENN, S.G.; LEBRILLA, C.B.; BROWN, P.H. Isolation and characterization of soluble boron complexes in higher plants. Plant Physiology, v.113, p.649-655, 1997.

ISHII, T.; MATSUNAGA, T. Isolation and characterization of a boron-rhamnogalacturonan. II. Complex from cell walls of sugar beet pulp. Carbohydrate Research, v.284, p.1-9, 1996.

ISHII T.; MATSUNAGA, T.; HAYASHI, N. Formation of rhamnogalacturonanII: borate dimer in pectin determines cell wall thickness of pumpkin tissue. Plant Physiology, v.126, p.1698-1705, 2001 .

JOHNSON, C.M.; STOUT, P.R.; BROYER, T.C.; CARTON, A.B. Comparative chlorine requirements of different plant especies. Plant and Soil, v.8, p.337-353, 1957
JOLY, A.B. Botânica: introdução à taxonomia vegetal. 13 ed. São Paulo: Companhia Editora Nacional, 2002. 777p.

KARNOVSKY, M.J. A formaldehyde glutaraldehyde fixative of high osmolarity for use in electron microscopy. Journal of Cell Biology, v.27, p.137-238, 1965.

KOBAYASHI, M.; MATOH, T.; AZUMA, J. Two chains of rhamnogalacturonan II are cross-linked by borate-diol ester bonds in higher plant cell walls. Plant Physiology, v.110, p.10171020, 1996

LANGE, A.; MARTINES, A.M.; SILVA, M.A.C. Micronutrient deficiency effect on the nutritional status of the castor bean cultivar Iris. Pesquisa Agropecuária Brasileira, v.40, p.61-67, 2005.

LEWIS, O.H. Boron, lignification and the origin of vascular plants: a unified hypothesis. New Phytologist, v.84, p.209-229, 1980.

LOUÉ, A. Oligo-éléments en agriculture. Antibes: Nathan, 1993. $557 p$

MALAVOLTA, E.; VITTI, G.C.; OLIVEIRA, S.A. Metodologia para análise de elemento em material vegetal. In: MALAVOLTA, E.; VitTi, G.C.; OLIVEIRA, S.A. Avaliação do estado nutricional das plantas: princípios e aplicações. 2 ed. Piracicaba: Associação Brasileira para Pesquisa da Potassa e do Fosfato, 1997. p.231-307.

MARSCHNER, H. Mineral nutrition of higher plants. London: Academic Press, 1995. 889p.

MATOH, T. Boron in plant cell walls. In: DELL, B.; BROWN, P.H.; BELL, R.W. Boron in soil and plants: reviews. London: Academic Press, 1997. v.193, p.59-70.

MATOH, T.; KAWAGUCHI, S.; KOBAYASHI, M. Ubiquity of a borate-rhamnogalacturonan. II. Complex in the cell walls of higher plants. Plant Cell Physiology, v.37, p.636-640, 1996.

MATOH, T.; KOBAYASHI, M. Boron in plant cell walls. In: GOLDBACH, H.E.; RERKASEM, B.; WIMMER, M.A.; BROWN, P.H.; THELLIER, M.; BELL, R.W. (Ed.) Boron in plant and animal nutrition. New York: Academic Press, 2002. p.143-155.

MATTOS JÚNIOR, D.; QUAGGIO, J.A.; CANTARELLA, H. Calagem e adubação dos citros. Informe Agropecuário, v.22, p.39-46, 2001.

O'NEILl, M.A.; WARRENFELTZ, D.; KATES, K.; PELLERIN, P.; DOCO, T.; DARVILL, A.G.; ALBERSHEIM, P. Rhamnogalacturonan. II. A pectic polysaccharide in the walls of growing plant cells, forms a dimer that is covalently crosslinked by a borate ester. Journal of Biological Chemistry, v.271, p.22923-22930, 1996.

PILBEAM, D.J.; KIRKBY, E.A. The physiological role of boron in plants. Journal of Plant Nutrition, v.6, p.563-582, 1983.

POLLARD, A.S.; PARR, A.J.; LOUGHMAN, B.C. Boron in relation to membrane function in higher plants. Journal of Experimental Botany, v.28, p.831-841, 1977.

REYNOLDS, E.S. The use of lead citrate at high $\mathrm{pH}$ as an eletronopaque stain in electron microscopy. Journal of Cell Biology, v.17, p.208-212, 1963.

SAVY FILHO, A. Mamona: tecnologia agrícola. Campinas: EMOPI, 2005. $105 \mathrm{p}$.

SCOTT, E.G. Effect of supra-optimal boron levels on respiration and carbohydrate metabolism of Helianthus annuus. Plant Physiology, v.35, p.653-661, 1960.

SHORROCKS, V.M. The occurrence and correction of boron deficiency. In: DELL, B.; BROWN, P.H.; BELL, R.W. Boron in soils and plants: reviews. Dordrecht: Kluwer Academic, 1997. p.121-148.

SHKOLNIK, M. Y. Trace elements in plants. Amsterdam: Elsevier, 1984. 463p.

ZRENNER, R.; SALANOUBAT, M.; WILLMITZER, L.; SONNEWALD, U. Evidence of the crucial role of sucrose synthase for sink strength using transgenic potato plants (Solanum tuberosum, L.). Plant Journal, v.7, p.97-107, 1995.

Received December 21, 2006

Accepted August 29, 2008 